\title{
Insulin Regulation of Renal Glucose Metabolism in Conscious Dogs
}

\author{
Eugenio Cersosimo, Robert L. Judd, and John M. Miles \\ Endocrine Research Unit, Division of Endocrinology and Metabolism, Mayo Clinic and Foundation, Rochester, Minnesota 55905
}

\begin{abstract}
Previous studies indicating that postabsorptive renal glucose production is negligible used the net balance technique, which cannot partition simultaneous renal glucose production and glucose uptake. $10 \mathrm{~d}$ after surgical placement of sampling catheters in the left renal vein and femoral artery and a nonobstructive infusion catheter in the left renal artery of dogs, systemic and renal glucose and glycerol kinetics were measured with peripheral infusions of $\left[3-{ }^{3} \mathrm{H}\right]$ glucose and $\left[2-{ }^{14} \mathrm{C}\right]$ glycerol. After baseline measurements, animals received a $2-h$ intrarenal infusion of either insulin $(n=6)$ or saline $(n=6)$. Left renal vein insulin concentration increased from $41 \pm 8$ to $92 \pm 23$ $\mathrm{pmol} / \mathrm{l}(\boldsymbol{P}<0.05)$ in the insulin group, but there was no change in either arterial insulin, $(\sim 50 \mathrm{pmol} / \mathrm{l})$, glucose concentrations $(\sim 5.4 \mathrm{mmol} / \mathrm{l})$, or glucose appearance $(\sim 18$ $\left.\mu \mathrm{mol} \cdot \mathrm{kg}^{-1} \cdot \mathrm{min}^{-1}\right)$. Left renal glucose uptake increased from $3.1 \pm 0.4$ to $5.4 \pm 1.4 \mu \mathrm{mol} \cdot \mathrm{kg}^{-1} \cdot \mathrm{min}^{-1}(P<0.01)$ while left renal glucose production decreased from $2.6 \pm 0.9$ to $0.7 \pm 0.5$ $\mu \mathrm{mol} \cdot \mathrm{kg}^{-1} \cdot \min ^{-1}(P<0.01)$ during insulin infusion. Renal gluconeogenesis from glycerol decreased from $0.23 \pm 0.06$ to $0.17 \pm 0.04 \mu \mathrm{mol} \cdot \mathrm{kg}^{-1} \cdot \mathrm{min}^{-1}(P<0.05)$ during insulin infusion.
\end{abstract}

These results indicate that renal glucose production and utilization account for $\sim \mathbf{3 0} \%$ of glucose turnover in postabsorptive dogs. Physiological hyperinsulinemia suppresses renal glucose production and stimulates renal glucose uptake by $\sim 75 \%$. We conclude that the kidney makes a major contribution to systemic glucose metabolism in the postabsorptive state. (J. Clin. Invest. 1994. 93:2584-2589.) Key words: kidney • glycerol • carbohydrate • gluconeogenesis • kinetics

\section{Introduction}

The role of the kidney in glucose metabolism is thought to be minor under most circumstances. Cahill et al. (1) demonstrated that net renal glucose output was negligible in the postabsorptive state, but it increased substantially with 4-6 wk of fasting, contributing nearly half of daily systemic glucose appearance in humans. Subsequent studies suggested that net renal glucose output during fasting reflected renal gluconeogenesis, primarily from circulating amino acids and glycerol $(2,3)$. More recently, similar studies in animals have again documented the ability of the kidney to significantly increase glu-

Address all correspondence to Eugenio Cersosimo, M.D., Ph.D., Division of Endocrinology, Department of Medicine, Stony Brook Health Science Center, T15-Room 060, SUNY-Stony Brook, NY, 117948154.

Received for publication 2 December 1993 and in revised form 28 January 1994.

J. Clin. Invest.

(c) The American Society for Clinical Investigation, Inc.

$0021-9738 / 94 / 06 / 2584 / 06 \$ 2.00$

Volume 93, June 1994, 2584-2589 cose output in conditions of insulin deficiency (4). Although these observations underscore the potential role of the kidney in glucose regulation in specific circumstances, they have been interpreted to indicate that the kidney is unimportant under most conditions. All in vivo studies suggesting a minimal role for the kidney in glucose metabolism in postabsorptive conditions (1-4) used the arteriovenous balance technique, a method which has limitations that have not been sufficiently emphasized. It is conceivable that glucose production could take place in one part of the kidney with simultaneous utilization of glucose occurring in a separate anatomic location in the same organ. If this were the case, the two processes would tend to cancel each other out and measurement of net renal glucose balance could lead to the erroneous conclusion that the kidney is not an important site of either glucose utilization or production.

Substantial in vitro evidence indicates that the kidney is capable of both glucose production and utilization. Krebs and co-workers $(5,6)$ demonstrated that the biochemical machinery is in place in cells of the proximal convoluted tubule to efficiently convert 3-carbon precursors to glucose, particularly glycerol and glutamine. At the same time, cells of the distal nephron and those in the interstitial medulla are very active in glucose uptake and oxidation $(7,8)$. If renal glucose production and utilization occur at significant rates and are divergently regulated, this would be of considerable potential significance. The present studies were therefore undertaken to determine whether simultaneous renal glucose production and utilization occur in conscious dogs, and whether these processes are responsive to physiological hyperinsulinemia, using arteriovenous balance measurements combined with a tracer technique.

\section{Methods}

Animals and surgery. Studies were performed in 20-25-kg female mongrel dogs $(n=12) .7-10 \mathrm{~d}$ before the experiment a laparotomy was performed under halothane anesthesia. A silastic sampling catheter (0.040" ID and 0.085 " OD) was placed midway into the left renal vein via the inferior vena cava and secured with a pursestring suture; the gonadal vein was ligated. In addition, a small (0.027" ID and 0.047" OD) nonobstructive infusion catheter was inserted into the midportion of the left renal artery and also secured with a pursestring suture. A third catheter was placed in the aorta via the left femoral artery. All catheters were filled with heparinized saline, ligated, and tunneled to a subcutaneous pocket as previously described (9). $1 \mathrm{wk}$ after surgery, all dogs had stable weight and $3 \mathrm{ml}$ of blood were drawn to determine leukocyte count and the hematocrit of the animal. Only those consuming two thirds or more of the daily ration, which contained $\sim 42-56 \mathrm{~g}$ of protein per day, and having a leukocyte count below $16,000 / \mu$ and a hematocrit $>38 \%$ were studied.

Experimental protocol. On the morning of the experiment, after an overnight fast, catheters were exteriorized under local anesthesia. An 8-Fr bladder catheter was placed and urine was collected at 30-min intervals throughout the study. An infusion catheter was inserted into the precava via a lateral saphenous vein, and kept patent with $0.9 \%$ 
$\mathrm{NaCl}$ at $30 \mathrm{ml} / \mathrm{h}$. At $0800(t=-120 \mathrm{~min})$, after obtaining blood and urine for assay blanks, a primed constant systemic infusion of $\left[3-{ }^{3} \mathrm{H}\right]-$ Glucose $(10 \mu \mathrm{Ci}, 0.20 \mu \mathrm{Ci} / \mathrm{min})$ and $\left[2-{ }^{14} \mathrm{C}\right]$ glycerol $(25 \mu \mathrm{Ci}, 0.50$ $\mu \mathrm{Ci} / \mathrm{min})$ together with a constant intrarenal indocyanine green (ICG) ${ }^{1}$ infusion $(0.08 \mathrm{mg} / \mathrm{min})$ were started and continued until the end of the study. Baseline femoral artery and renal vein blood samples were obtained every $10 \mathrm{~min}$ from -30 to $0 \mathrm{~min}$ for the measurement of left renal plasma flow, plasma-free fatty acid concentrations, and glucose and glycerol concentrations and specific activities. Arterial hematocrit was measured at the beginning and at the end of the experiment.

After completion of baseline collections, a 2-h intrarenal infusion of insulin at $0.05 \mathrm{mU} \cdot \mathrm{kg}^{-1} \cdot \mathrm{min}^{-1}$ or saline was begun. The insulin infusion rate was selected to reproduce in the renal artery the normal postprandial increase in plasma insulin, from $\sim 10$ to $\sim 20 \mu \mathrm{U} / \mathrm{ml}$ in $\operatorname{dogs}(10)$, assuming unilateral renal plasma flow of $7 \mathrm{ml} \cdot \mathrm{kg}^{-1} \cdot \mathrm{min}^{-1}$ (11). Blood samples were obtained again at 10 -min intervals between 90 and $120 \mathrm{~min}$. At the end of the experiment, the dog was euthanized with an intravenous infusion of a solution of phenobarbital and concentrated potassium chloride; the position of the catheters were verified at necropsy.

Analytical techniques. Plasma glucose was measured with the YSI glucose analyzer ( Yellow Springs, IL). Plasma ICG was determined by colorimetric assay (12) and insulin by radioimmunoassay (13). $\left[{ }^{3} \mathrm{H}\right]-$ glucose specific activity (SA) as determined in deproteinized plasma (14) after deionization with ion exchange resins; glycerol concentration and SA was determined by reverse phase high performance liquid chromatography (HPLC) (15). This HPLC procedure also allows for isolation and collection of glucose so that the ${ }^{3} \mathrm{H}:{ }^{14} \mathrm{C}$ ratio in glucose can be determined. Plasma FFA was measured by HPLC (16).

Calculations. Left renal plasma flow (LRPF) was calculated by ICG dilution using the following equation:

$$
\mathrm{LRPF}=I N F /[\mathrm{ICG}]_{\mathrm{rv}}-[\mathrm{ICG}]_{\mathrm{a}}
$$

where INF = ICG infusion rate $(\mathrm{mg} / \mathrm{min}) ;[$ ICG $]=$ plasma ICG concentration $(\mathrm{mg} / \mathrm{dl}) ; \mathrm{rv}=$ renal vein; and $\mathrm{a}=$ artery. $\mathrm{LRPF}$ was converted to blood flow by dividing it by (1-hematocrit). In preliminary studies, the values obtained by the ICG dilution technique agreed closely with those obtained by doppler flow probe. Left and right renal blood flow measured by doppler were also nearly identical. The ICG dilution technique was used in the present study because the intrarenal infusion catheter appears to interfere with doppler readings of the left renal artery in preliminary experiments.

Whole body glucose rate of appearance $\left(R_{a}\right)$ was calculated using the steady-state formula:

Glu $R_{\mathrm{a}}=I N F /{ }^{3} \mathrm{H}$ Glu $\mathrm{SA}_{\mathrm{a}}$

where INF is the $\left[3-{ }^{3} \mathrm{H}\right]$ glucose infusion rate $(\mathrm{dpm} / \mathrm{min})$.

Left renal fractional extraction of glucose $\left(\mathrm{FE}_{\mathrm{g}}\right)$ was calculated using the following formula:

$\mathrm{FE}_{\mathrm{g}}=\left([\mathrm{Glu}]_{\mathrm{a}} \times \mathrm{Sa}_{\mathrm{a}}-[\mathrm{Glu}]_{\mathrm{rv}} \times \mathrm{SA}_{\mathrm{rv}}\right) /\left([\mathrm{Glu}]_{\mathrm{a}} \times \mathrm{SA}_{\mathrm{a}}\right)$

where $[\mathrm{Glu}]=$ plasma glucose concentration and SA refers to tritiated glucose specific activity. The numerator in this formula represents $\left[{ }^{3} \mathrm{H}\right]$ glucose radioactivity extracted by the kidney and the denominator represents arterial ${ }^{3} \mathrm{H}$ glucose radioactivity.

Left renal glucose uptake was calculated using the formulae,

Uptake $=\mathrm{FE}_{\mathrm{g}} \times[\mathrm{Glu}]_{\mathbf{a}} \times \mathrm{LRPF}$

Since glycosuria was not present, left renal glucose utilization was assumed to be equal to glucose uptake.

Left renal glucose production was calculated using the following formula:

1. Abbreviations used in this paper: ICG, indocyanine green; INF, infusion rate; HPLC, high performance liquid chromatography; LRPF, left renal plasma flow; $R_{a}$, rate of appearance; $S A$, specific activity.
Production $=$ Uptake $+\left([\mathrm{Glu}]_{\mathrm{rv}}-[\mathrm{Glu}]_{\mathrm{a}}\right) \times \mathrm{LRPF}$

$\left[{ }^{14} \mathrm{C}\right]$ glucose $\mathrm{SA}$ was calculated as follows:

$\left[{ }^{14} \mathrm{C}\right]$ glucose $\mathrm{SA}=\left[{ }^{3} \mathrm{H}\right]$ glucose $\mathrm{SA} /{ }^{3} \mathrm{H}:{ }^{14} \mathrm{C}$ ratio in glucose

The percent of systemic glucose production derived from glycerol was calculated using the following formula:

$\%$ Glu $R_{\mathrm{a}}$ from Glycerol

$=\left({ }^{14} \mathrm{C}_{\text {Glu SA }} /{ }^{14} \mathrm{C}-\right.$ Glycerol SA $\left.\mathrm{a}\right) \times 100 / 2$

This is a standard product-precursor calculation which takes into account the fact that 2 moles of glycerol are required to produce 1 mole of glucose. The rate of glycerol-derived gluconeogenesis (Gly $\rightarrow$ Glu) was calculated using the following formula:

Gly $\rightarrow$ Glu $=\%$ glucose $R_{\mathrm{a}}$ from glycerol $\times$ Glu $R_{\mathrm{a}}$

The contribution of the kidney to the rate of appearance of $\left[{ }^{14} \mathrm{C}\right]-$ glucose derived from glycerol was obtained from the following formula:

LRPF $\times\left({ }^{14} \mathrm{C} \mathrm{Glu} \mathrm{SA} A_{\mathrm{rv}} \times[\mathrm{Glu}]_{\mathrm{rv}}\right)$
$\frac{-\left(1-\mathrm{FE}_{\mathrm{g}}\right) \cdot\left({ }^{14} \mathrm{C} \mathrm{Glu} \mathrm{SA_{ \textrm {a } }} \times[\mathrm{Glu}]_{\mathrm{a}}\right)}{2\left({ }^{14} \mathrm{C} \mathrm{Gly} \mathrm{SA} \mathrm{A}_{\mathrm{a}}\right)}$

The numerator in the formula represents the renal vein glucose $\left[{ }^{14} \mathrm{C}\right]-$ glucose radioactivity in excess of that anticipated from the known arterial glucose ${ }^{14} \mathrm{C}$ radioactivity and the fractional extraction of ${ }^{3} \mathrm{H}$ glucose (i.e., that $\left[{ }^{14} \mathrm{C}\right]$ glucose which has been newly generated in the kidney). The denominator in the formula is the precursor pool (glycerol) specific activity in $\mathrm{dpm} / \mu \mathrm{mol}$, again taking into account the fact that 2 moles of glycerol are required to generate 1 mole of glucose. This formula will underestimate actual renal gluconeogenesis from glycerol to the extent that the kidney metabolizes newly synthesized $\left[{ }^{14} \mathrm{C}\right]$ glucose.

Statistics. All values are expressed as mean \pm SEM. Data obtained at baseline in each group were compared to those from the study period using a paired $t$ test; data between groups following intrarenal infusions were compared using nonpaired $t$ test. All $P$ values $<0.05$ were considered statistically significant (17).

\section{Results}

Arterial insulin levels were similar in the insulin and the saline groups, before and during the infusions, respectively (Table I). During intrarenal infusion, renal vein insulin concentration more than doubled in the insulin group $(P<0.05)$, whereas there was no change in the saline group pmol/1) (Table I). Left renal plasma flow at baseline was $4.0 \pm 1.0 \mathrm{ml} \cdot \mathrm{kg}^{-1} \cdot \mathrm{min}^{-1}$ in the insulin group and $4.9 \pm 0.6 \mathrm{ml} \cdot \mathrm{kg}^{-1} \cdot \mathrm{min}^{-1}$ in the saline group, and remained comparable ( $P=\mathrm{NS}$ ) during the study period $\left(4.7 \pm 0.8\right.$ and $5.5 \pm 1.4 \mathrm{ml} \cdot \mathrm{kg}-1 \cdot \mathrm{min}^{-1}$, in the insulin and saline groups, respectively).

Fig. 1 shows plasma glucose concentration during the baseline and study periods. Arterial plasma glucose averaged $5.4 \pm 0.2$ and $5.4 \pm 0.1 \mathrm{mmol} / 1$ in the insulin group and 5.6 \pm 0.2 and $5.5 \pm 0.2 \mathrm{mmol} / 1$ in the saline group during the baseline and study periods, respectively. Baseline renal vein glucose concentrations decreased from $5.3 \pm 0.2$ to $4.9 \pm 0.1 \mathrm{mmol} / 1$ during intrarenal infusion in the insulin group $(P<0.05)$, but no change was observed in the saline group ( $5.5 \pm 0.2$ vs. $5.5 \pm 0.3 \mathrm{mmol} / 1, P=\mathrm{NS}$ ). As a consequence, net glucose balance in the insulin group changed from $+0.10 \pm 0.04 \mathrm{mmol} / 1$ at baseline to $+0.51 \pm 0.04 \mathrm{mmol} / 1$ after intrarenal insulin infusion $(P<0.01)$, but did not change significantly after intrarenal saline infusion $(+0.20 \pm 0.08$ vs. $+0.03 \pm 0.08 \mathrm{mmol} / 1 \mathrm{dur}-$ ing the baseline and study periods, respectively, $P=\mathrm{NS}) .\left[{ }^{3} \mathrm{H}\right]-$ 
Table I. Arterial and Renal Venous Insulin Concentrations (pmol/l) in the Insulin and Saline Groups

\begin{tabular}{llllll}
\hline & \multicolumn{2}{c}{ Arterial } & & \multicolumn{2}{c}{ Renal vein } \\
\cline { 2 - 3 } \cline { 6 - 6 } & Baseline & Study & & Baseline & Study \\
\hline Insulin & $54 \pm 7$ & $54 \pm 10$ & & $41 \pm 8$ & $92 \pm 23^{*}$ \\
Saline & $39 \pm 3$ & $36 \pm 1$ & & $28 \pm 3$ & $24 \pm 3$ \\
\hline
\end{tabular}

$* P<0.05$.

glucose SA was stable throughout the baseline and study periods in all experiments (Fig. 2), but was consistently lower in the renal vein than in the artery during the baseline period in both groups $(P<0.05)$. During intrarenal infusion renal vein glucose SA increased significantly (from $845 \pm 50$ to $945 \pm 55$ $\mathrm{dpm} / \mu \mathrm{mol}, P<0.05$ ) in the insulin group but did not change $(890 \pm 100$ vs. $920 \pm 80 \mathrm{dpm} / \mu \mathrm{mol}, P=\mathrm{NS}$ ) in the saline group.

Systemic glucose $\mathrm{Ra}$ was $17.7 \pm 0.8$ and $19.3 \pm 1.8$ $\mu \mathrm{mol} \cdot \mathrm{kg}^{-1} \cdot \mathrm{min}^{-1}$ in the insulin and saline groups, respectively $(P=\mathrm{NS})$, and decreased slightly, but not significantly, during intrarenal infusion (to $17.1 \pm 0.6$ and $17.2 \pm 1.0$ $\mu \mathrm{mol} \cdot \mathrm{kg}^{-1} \cdot \mathrm{min}^{-1}$ in the insulin and saline groups, respectively). Left renal glucose uptake (Fig. 3) increased from $3.1 \pm 0.4$ to $5.4 \pm 1.4 \mu \mathrm{mol} \cdot \mathrm{kg}^{-1} \cdot \mathrm{min}^{-1}$ during intrarenal infusion in the insulin group $(P<0.01)$, whereas no change occurred in the saline group $(2.7 \pm 0.5$ vs $2.4 \pm 1.0$ $\left.\mu \mathrm{mol} \cdot \mathrm{kg}^{-1} \cdot \mathrm{min}^{-1}, P=\mathrm{NS}\right)$. After intrarenal infusion, left renal glucose production (Fig. 4 ) decreased by $75 \%$ in the insulin group (from $2.6 \pm 0.9$ to $0.7 \pm 0.5 \mu \mathrm{mol} \cdot \mathrm{kg}^{-1} \cdot \mathrm{min}^{-1}, P<$ 0.01 ), while a nonsignificant increase occurred in the saline group ( $1.8 \pm 1.0$ vs $\left.2.4 \pm 1.0 \mu \mathrm{mol} \cdot \mathrm{kg}^{-1} \cdot \mathrm{min}^{-1}, P=\mathrm{NS}\right)$.

Plasma $\left[{ }^{14} \mathrm{C}\right]$ glucose $\mathrm{SA}$ and $\left[{ }^{14} \mathrm{C}\right]$ glycerol SA were stable during the baseline and study periods in all experiments (data not shown) indicating steady-state conditions had been achieved. After intrarenal insulin infusion, arterial $\left[{ }^{14} \mathrm{C}\right]-$ glucose SA did not change ( $1336 \pm 97$ vs $1471 \pm 175 \mathrm{dpm} / \mu \mathrm{mol}$, $P=$ NS) but a significant increase (from $1580 \pm 292$ to $2073 \pm 207 \mathrm{dpm} / \mu \mathrm{mol}, P<0.05)$ was observed in the saline group. Similarly, renal vein $\left[{ }^{14} \mathrm{C}\right]$ glucose $\mathrm{SA}$ did not change in the insulin group $(1178 \pm 134$ vs $1360 \pm 198 \mathrm{dpm} / \mu \mathrm{mol}, P$ $=$ NS), but it increased significantly in the saline group (from

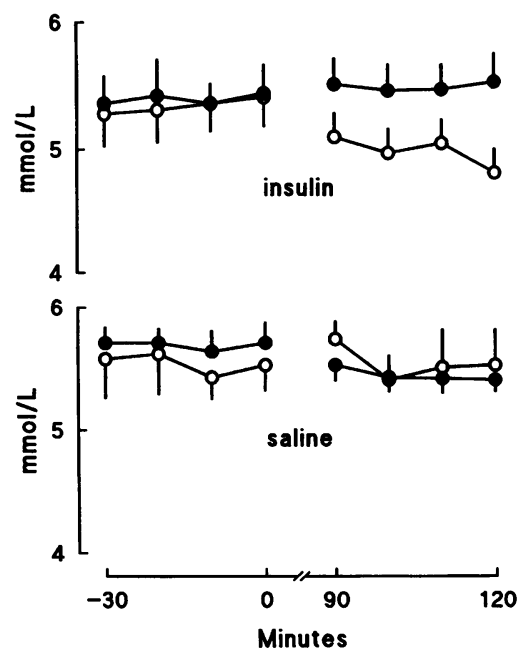

Figure 1. Arterial (•) and renal vein $(0)$ glucose concentrations during baseline $(-30-0$ min) and study (90-120 min) periods in the insulin (upper panel) and saline (lower panel) groups.

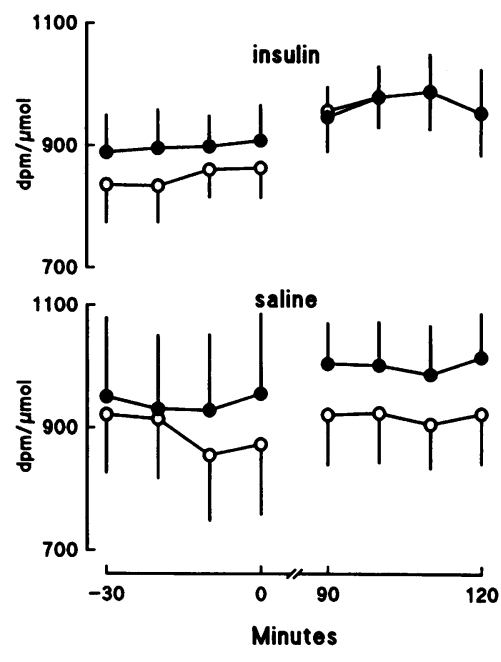

Figure 2. Arterial (•) and renal vein $(0)$ glucose specific activity during baseline and study periods in the insulin group (upper panel) and saline (lower panel) groups.
$1533 \pm 196$ to $1980 \pm 172 \mathrm{dpm} / \mu \mathrm{mol}, P<0.05)$. Arterial $\left[{ }^{14} \mathrm{C}\right]-$ glycerol SA increased slightly following intrarenal insulin from an average $7.9 \pm 0.9$ to $8.8 \pm 0.5 \mathrm{dpm} / \mathrm{nmol}(P<0.05)$ but did not change following intrarenal saline infusion $(6.4 \pm 0.5$ vs $6.3 \pm 0.8 \mathrm{dpm} / \mathrm{nmol}, P=\mathrm{NS})$. Arterial glycerol concentration decreased from $92 \pm 8$ to $76 \pm 10 \mu \mathrm{mol} / \mathrm{L}(P<0.05)$ in the insulin group and did not change in the saline group ( $76 \pm 6$ vs $81 \pm 7$ $\mu \mathrm{mol} / \mathrm{l}, P=\mathrm{NS})$. Plasma FFA concentration decreased from $702 \pm 33$ to $604 \pm 14 \mu \mathrm{mol} / 1$ in the insulin group $(P<0.05)$, whereas there was no effect in the saline group (606 \pm 68 vs $616 \pm 65 \mu \mathrm{mol} / 1, P=\mathrm{NS}$ ). Systemic glycerol $\mathrm{Ra}$ increased slightly, but not significantly, after intrarenal saline infusion but decreased $(P<0.05)$ following intrarenal insulin infusion (Table II). Systemic gluconeogenesis from glycerol declined ( $P$ $<0.05)$ by $\sim 30 \%$ following IR insulin infusion, whereas it did not change in the saline group $(P=\mathrm{NS})$. Likewise, renal gluconeogenesis from glycerol decreased $(P<0.05)$ by $\sim 25 \%$ after intrarenal insulin infusion, but did not change in response to intrarenal saline $(P=\mathrm{NS})$.

\section{Discussion}

The present studies confirm previous studies in dogs (4) and humans (1-3) indicating that net renal glucose balance in the postabsorptive state is close to zero. However, the combination of the net balance technique and tracer infusion in our study documents the simultaneous occurrence of glucose production

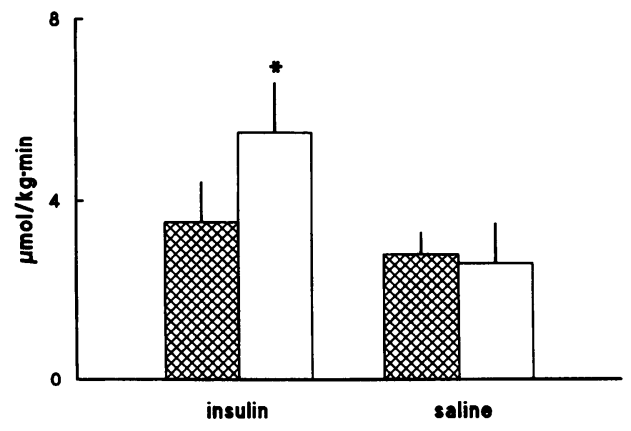

Figure 3. Left renal glucose uptake in $\mu \mathrm{mol} / \mathrm{kg}$ of body weight per minute during baseline ( $\square$ ) and study ( $\square$ ) periods in the two groups. ${ }^{*} P<0.01$ vs baseline and control. 


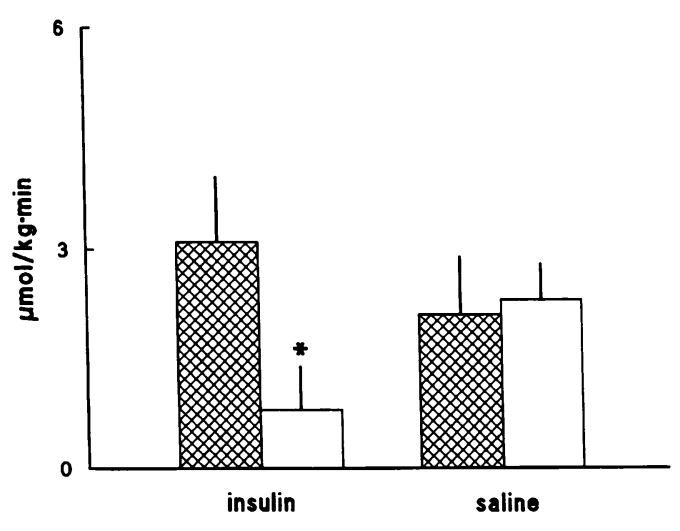

Figure 4. Left renal glucose output during baseline ( $\square$ ) and study ( $\square$ ) periods in the two groups. ${ }^{*} P<0.01$ vs baseline and control.

and uptake by the kidney at approximately equal rates. Our observation that the kidney accounts for $\sim 30 \%$ ( $15 \%$ in each kidney) of systemic glucose turnover strongly contrasts with the prevailing view that the liver is the only significant source of glucose production in the postabsorptive state (18). Moreover, the evidence that one quarter to one third of systemic glucose disappearance occurs in the kidney demonstrates the potential impact of changes in renal glucose uptake on overall glucose homeostasis. These observations require a more complicated model of glucoregulation, taking into consideration possible different effects on the kidney and liver of the large number of hormones (19-21) and substrates (22-24) known to affect systemic glucose metabolism.

The approximate equality of renal glucose production and utilization, which results in modest to negligible net glucose balance, could be interpreted to indicate that the role of these two processes in whole body glucose homeostasis during the postabsorptive period is minimal. However, the divergent effects of physiological increases in plasma insulin concentration on renal glucose production and utilization (suppression and stimulation, respectively) underscore the potential importance of changes in renal glucose metabolism on systemic glucoregulation, both in normal physiology and in disease states such as diabetes mellitus and chronic renal insufficiency.

The combination of arteriovenous balance and isotope dilution can effectively partition uptake and release in a tissue bed and has been previously applied to the study of glucose, fatty acid, and amino acid metabolism in such diverse tissues as liver (25), kidney (26), and extremity $(27,28)$. The principle

Table II. Whole Body Glycerol $R_{a}$ and Gluconeogenesis from Glycerol (Gly $\rightarrow$ Glu) in $\mu \mathrm{mol} \cdot \mathrm{kg}^{-1} \cdot \mathrm{min}^{-1}$ in the Insulin and Saline Control Groups

\begin{tabular}{|c|c|c|c|c|}
\hline & \multicolumn{2}{|c|}{ Insulin } & \multicolumn{2}{|c|}{ Saline } \\
\hline & Baseline & Study & Baseline & Study \\
\hline $\begin{array}{l}\text { Whole body } R_{a} \\
\text { Whole body }\end{array}$ & $7.30 \pm 0.30$ & $6.60 \pm 0.40^{*}$ & $7.10 \pm 0.60$ & $7.50 \pm 0.20$ \\
\hline Gly $\rightarrow$ Glu & $1.78 \pm 0.20$ & $1.21 \pm 0.20^{*}$ & $1.65 \pm 0.20$ & $1.75 \pm 0.20$ \\
\hline Renal Gly $\rightarrow$ Glu & $0.24 \pm 0.06$ & $0.17 \pm 0.03^{*}$ & $0.21 \pm 0.06$ & $0.19 \pm 0.04$ \\
\hline
\end{tabular}

${ }^{*} P<0.05$. of this technique is that uptake of tracer and tracee from arterial blood is equivalent, so that the process of uptake does not influence plasma specific activity. Release of unlabeled tracee, on the other hand, results in dilution of tracer and lowers specific activity in the exiting venous blood. It should be recognized that the method provides only minimum estimates of uptake and release since tracers taken up by the tissue may be subsequently released, thus raising venous blood specific activity. For example, if $\left[3{ }^{3} \mathrm{H}\right]$ glucose is taken up by cells in the distal nephron, cycled through glycogen, and subsequently released as glucose in the peritubular space to the venous system, this would result in an underestimate of both renal glucose uptake and production. Studies combining $\left[2-{ }^{3} \mathrm{H}\right]$ glucose and [ $3-{ }^{3} \mathrm{H}$ ] glucose infusion would be useful in addressing this possibility, since ${ }^{3} \mathrm{H}$ is lost from the 2-position in glucose during cycling through glycogen (29), whereas ${ }^{3} \mathrm{H}$ in the 3-position is not. Furthermore, renal glucose production and utilization using $3\left[{ }^{3} \mathrm{H}\right]$ glucose tracer may be overestimated to the extent that detritiation occurs during futile cycling between dihydroxiacetone-phosphate and glycerol-phosphate.

Direct intrarenal infusion of insulin permits investigation of the effects of hyperinsulinemia on renal metabolism without inducing a major perturbation of systemic substrate metabolism. Our data show that physiological hyperinsulinemia suppresses renal glucose output by $75 \%$ and stimulates renal glucose uptake by $75 \%$, resulting in a change in net renal glucose balance from zero to net uptake. The intrarenal insulin infusion rate used in these studies $\left(0.05 \mathrm{mU} \cdot \mathrm{kg}^{-1} \cdot \mathrm{min}^{-1}\right)$ was selected to produce insulin levels in renal plasma in a range similar to that which occurs in the postprandial period in dogs (10). A twofold increase in left renal vein insulin concentration was observed, but systemic arterial insulin levels remained the same.

Although arterial plasma glucose concentration and systemic glucose $\mathrm{Ra}$ did not change following intrarenal insulin infusion, plasma FFA and glycerol concentrations decreased by $\sim 20 \%$ and systemic glycerol Ra decreased by $\sim 10 \%$, suggesting that insulin recirculation through the left renal vein was sufficient to exert an inhibitory effect on adipose tissue lipolysis. This is not entirely surprising, in view of the previously demonstrated high sensitivity of lipolysis to small changes in plasma insulin levels (30). We have performed separate studies in which insulin was infused systemically at a rate similar to the rate of intrarenal insulin infusion used in the present study; in those experiments, a comparable degree of inhibition of adipose tissue lipolysis was observed but there was no effect on renal or systemic glucose production (unpublished observations). It is therefore unlikely that the $\sim 20 \%$ decrease in plasma FFA was responsible for the degree of inhibition of renal glucose release observed in the present studies. Additional studies will be required to assess the role of plasma FFA concentrations, which are known to influence rates of hepatic gluconeogenesis (31), on renal glucose production. The $\sim 25 \%$ decrease in systemic gluconeogenesis from glycerol is likely entirely the result of a proportional decrease in glycerol availability.

According to our findings, glycerol-derived gluconeogenesis accounts for $\sim 10 \%$ of systemic and renal glucose production, and $\sim 20 \%$ of total glycerol conversion to glucose occurs in the kidney ( $\sim 10 \%$ in each kidney). During intrarenal insulin infusion renal glucose output decreased by $\sim 75 \%$, while renal glycerol conversion to glucose decreased only slightly, 
representing $\sim 25 \%$ of renal glucose output during insulin infusion. In fact, it is not at all unlikely that the decrease in renal conversion of glycerol to glucose reflects a mere reduction in glycerol availability, similar to systemic gluconeogenesis from glycerol, and that insulin has minimal or no direct effect on renal gluconeogenesis from glycerol. These findings strongly suggest that suppression of renal glucose production by physiological hyperinsulinemia is due primarily to an inhibitory effect on renal glycogenolysis. However, the data could also reflect inhibition by insulin of gluconeogenesis from substrates other than glycerol, such as glutamine. In either case, our results are concordant with other reports $(4,32)$ which indicate that insulin, similar to its effect in the liver (33), inhibits renal glucose production. The effects of insulin in situations where concentrations of glucose and other substrates are changing, such as occurs after a mixed meal, are difficult to predict and their elucidation will require further study.

Stimulation of renal glucose uptake by insulin may reflect effects on both oxidative and non-oxidative glucose disposal, similar to its action on peripheral tissues (34). Glucose utilization is minimal in the proximal convoluted tubule (35), whereas active anaerobic glycolysis with lactate formation (36) and glycogen synthesis and storage (37) occur in the distal nephron. Oxidative glucose disposal is only known to occur to a significant extent in the interstitial medullary cells (38). The insulin-mediated increase in renal glucose uptake in our study thus likely occurs in the distal nephron, and may reflect an enhancement in both glycogen synthesis and glucose oxidation. Glycogen deposition has been documented in the distal nephron in humans (39). The fact that glycogen accumulation in the ascending limb of the loop of Henle was reported in hyperglycemic rats (40) and in poorly controlled diabetic patients (39) has been taken as evidence that glycogen synthesis and storage in the distal nephron is essentially dependent upon glucose supply (41). Since the predominant effect of insulin in our study appears to be on distal nephron glycogenolysis, and not on proximal tubular gluconeogenesis, there should not have been a decrease in glucose supply to the distal nephron. Therefore, insulin may have stimulated glycogen synthesis and simultaneously inhibited glycogenolysis in the distal nephron. Alternatively, the insulin-mediated increase in renal glucose uptake may be due solely to increased renal medullary glucose oxidation. It is well established that insulin stimulates sodium tubular transport (42), an effect that occurs predominantly in the diluting segment of the distal nephron (43). Since active transport in these segments of the nephron appears to be partly dependent upon glucose oxidation (41), enhancement of sodium transport by insulin could have induced oxidation of glucose to meet increasing energy requirements. Additional studies are needed in which the effects of insulin on both renal uptake and oxidation of glucose are measured.

Review articles and textbooks chapters on glucose metabolism $(18,44,45)$ suggest that $\sim 25 \%$ of whole body glucose utilization in the postabsorptive state occurs in blood cells and renal medulla. These figures are obtained by exclusion (after measurements of uptake by brain), since to our knowledge no studies have heretofore been performed which have quantified either renal or blood cell glucose utilization rates. Our results in postabsorptive dogs suggest that the majority of this unmeasured glucose uptake occurs in the kidney. Since net renal glucose output in the postabsorptive state is near zero, the substantial net renal glucose output observed in fasting (1-3) or dia- betes (4) could be the result of a marked decrease in glucose uptake, an increase in renal glucose production, or a combination of the two. Increased gluconeogenesis (46) appears to be an important mechanism by which diabetic individuals maintain higher glucose turnover rates, and is a direct consequence of impaired insulin secretion and action (47). The relative contribution of direct effects of insulin deficiency and impaired insulin action versus indirect effects of increased circulating substrates (31) to increased hepatic or renal gluconeogenesis in diabetes is not known. Conversely, an imbalance between renal glucose production and utilization could result in a substantial decrease in net renal glucose output which would contribute to lower plasma glucose concentrations. In fact, hypoglycemia is a frequent occurrence in hospitalized patients with chronic renal insufficiency (48). The proportionately greater loss of renal cortex compared to medulla in chronic renal diseases (49) could create a situation in which renal glucose production is impaired while renal glucose uptake is relatively preserved.

In summary, we have demonstrated that the kidney is responsible for $\sim 30 \%$ of endogenous glucose turnover in the postabsorptive state in conscious dogs. Physiological hyperinsulinemia suppresses renal glucose production and stimulates glucose uptake. Since renal glycerol conversion to glucose was minimally affected, insulin may exert a primary inhibitory effect on renal glycogen degradation. Renal glucose utilization reflects renal glycogen synthesis and storage as well as glucose oxidation in the distal nephron.

\section{Acknowledgments}

We thank M. Persson for excellent technical assistance and A. Pelot for editorial help.

This work was supported in part by grants from the American Diabetes Association, Minnesota affiliate, and the U.S. Public Health Service (DK38092).

\section{References}

1. Cahill, G. F., Jr., M. G. Herrera, and A. P. Morgan. 1966. Hormone-fuel interrelationships during fasting. J. Clin. Invest. 45:1751-1769.

2. Owen, O. E., P. Felig, A. P. Morgan, J. Wahren, and G. F. Cahill, Jr. 1969 Liver and kidney metabolism during prolonged starvation. J. Clin. Invest. 45:574-583.

3. Felig, P., O. E. Owen, J. Wahren, and G. F. Cahill, Jr. 1969. Amino acid metabolism during prolonged fasting. J. Clin. Invest. 48:584-594.

4. Adrogue, H. J., J. P. Comstock, J. Pena, C. Hartley, M. Entman, and M. N. Rashad. 1990. Large renal glucose production (RGP) in conscious diabetic dogs without acidosis. Diabetes. 39:24A. (Abstr.)

5. Krebs, H. A., R. Hems, and T. Gascoyne. 1963. Renal gluconeogenesis IV: gluconeogenesis from substrate combinations. Acta Biol. Med. Ger. 11:607-615.

6. Krebs, H. A. 1980. Glutamine metabolism in the animal body. In Glutamine Metabolism, Enzymology and Regulation. Academic Press, New York. 319-329.

7. Weidemann, M. J., and H. A. Krebs. 1969. The fuel of respiration of rat renal cortex. Biochem. J. xx:149-165.

8. Guder, W., and B. D. Ross. 1984. Enzyme distribution along the nephron. Kidney Int. 26:101-111.

9. Abumrad, N. N., K. L. Wise, P. E. Williams, N. A. Abumrad, and W. W. Lacy. 1982. The disposal of $\alpha$-ketoisocaproate: roles of the liver, gut and kidneys. Am. J. Physiol. 243:E123-E131.

10. Cersosimo, E., P. Williams, P. Radosevich, B. Hoxworth, W. W. Lacy, and N. N. Abumrad. 1986. Glutamine blocks lipolysis and ketogenesis of fasting. Am. J. Physiol. 13:310-318.

11. Pitts, R. F. 1974. Physiology of kidney and body fluids. Yearbook Medical Publisher, Inc., New York. 240 pp.

12. Leevy, C. M. 1962. Estimation of hepatic blood flow with indocyanine green. J. Clin. Invest. 41:1169-1179.

13. Herbert, V., K. Lau, C. W. Gotlieb, and S. J. Bleicher. 1965. Coated charcoal immunoassay of insulin. J. Endocrinol. Metab. 25:1375-1384. 
14. Somogyi, M. 1945. Determination of blood sugar. J. Biol. Chem. 160:6974.

15. Judd, R., S. Klein, D. Morse, R. Fisher, S. Coppack, and J. M. Miles. 1993. A new HPLC method for the determination of plasma glycerol kinetics. FASEB (Fed. Am. Soc. Exp. Biol.) J. 7:265. (Abstr.)

16. Miles, J. M., M. G. Ellman, K. L. McClean, and M. D. Jensen. 1987. Validation of a new method for determination of free fatty acid turnover. Am. J. Physiol. 252:E431-E438.

17. Rosner, B. 1990. Fundamentals of Biostatistics. PWS-Kent, Boston, MA. $655 \mathrm{pp}$.

18. Cahill, G. F., Jr. 1970. Starvation in man. N. Engl. J. Med. 282:668-675.

19. Cherrington, A. D., P. E. Williams, and G. I. Shulman. 1981. Differential time-course of glucagon's effect on glycogenolysis and gluconeogenesis in the conscious dogs. Diabetes. 30:180-187.

20. Rizza, R. A., P. E. Cryer, and M. W. Haymond. 1980. Adrenergic mechanism for the effect of epinephrine on glucose production and clearance in man. $J$. Clin. Invest. 65:682-689.

21. Shamoon, H., R. Hendler, and R. S. Sherwin. 1981. Synergistic interactions among anti-insulin hormones in the pathogenesis of stress hyperglycemia in humans. J. Endocrinol. Metab. 52:1235-1241.

22. Randle, P. J., E. A. Newsholme, and P. B. Garland. 1964. Regulation of glucose uptake by muscle. Biochem. J. 93:652-665.

23. Crespin, S. R., W. B. Greenough III, and D. Steinberg. 1972. Effect of sodium linoleate infusion on plasma free fatty acids, glucose, insulin and ketones in unanesthetized dogs. Diabetes. 21:1179-1184.

24. Pisters, P., N. P. Restifo, E. Cersosimo, and M. F. Brennan. 1991. The effects of euglycemic hyperinsulinemia and amino acid infusion on regional and whole body glucose disposal in man. Metabolism. 40(1):59-65.

25. Abumrad, N. N., L. S. Jefferson, S. R. Rannels, P. E. Williams, A. D Cherrington, and W. W. Lacy. 1982. Role of insulin in the regulation of leucine kinetics in the conscious dogs. J. Clin. Invest. 70:1031-1041.

26. Bleiberg, B., T. R. Beers, M. Persson, and J. Miles. 1992. Systemic and regional acetate kinetics in dogs. Am. J. Physiol. 25:E197-E202.

27. Hagenfeldt, L., and J. Wahren. 1968. Human forearm muscle metabolism during exercise II: uptake, release and oxidation of individual FFA and glycerol. Scand. J. Clin. Lab. Invest. 21:263-273.

28. Barrett, E. J., J. H. Revkin, L. H. Young, B. L. Zaret, R. Jacob, and R. A Gelfand. 1987. An isotope method for measurement of muscle protein synthesis and degradation in vivo. Biochem. J. 245:223-228.

29. Bell, P., R. Firth, and R. A. Rizza. 1989. Assessment of the postprandia pattern of glucose metabolism in nondiabetic subjects and patients with noninsulin-dependent diabetes mellitus: Influences of futile cycling and cycling through glycogen. Metabolism. 38:38-45.

30. Jensen, M. D., M. Caruso, V. Heiling, and J. M. Miles. 1989. Insulin regulation of lipolysis in nondiabetic and IDDM subjects. Diabetes. 38:15951601.

31. Nurjhan, N., and J. Gerich. 1992. Increased lipolysis and its consequences on gluconeogenesis in non-insulin dependent diabetes mellitus. J. Clin. Invest. 89:169-175.
32. Kida, K., S. Nakajo, F. Kamiya, Y. Toyama, T. Nishio, and H. Nakagawa. 1978. Renal net glucose release in vivo and its contribution to blood glucose in rats. J. Clin. Invest. 62:721-726.

33. Rizza, R. A., L. Mandarino, and J. E. Gerich. 1981. Dose-response characteristics for the effects of insulin on production and utilization of glucose in man. Am. J. Physiol. 240:630-639.

34. Groop, L., R. Bonnadonna, S. DelPrato, K. Ratheiser, K. Zyck, E. Ferrannini, and R. DeFronzo. 1989. Glucose and free fatty acid metabolism in noninsulin dependent diabetes mellitus. J. Clin. Invest. 84:205-213.

35. Klein, K. L., M. S. Wang, S. Torikai, W. D. Davidson, and K. Kenokawa. 1981. Substrate oxidation by isolated single nephron segments of the rat. Kidney Int. 20:29-35.

36. Lee, J. B., V. K. Vance, and G. F. Cahill, Jr. 1962. Metabolism of ${ }^{14} \mathrm{C}$-labelled substrates by rabbit cortex and medulla. Am. J. Physiol. 203:27-38.

37. Khandelwal, R. L., S. M. Zinman, and H. R. Knull. 19798. The effect of streptozotocin-induced diabetes on glycogen metabolism in rat kidney and its relationship to the liver system. Arch. Biochem. Biophys. 197:310-316.

38. Abodeely, D. A., and J. B. Lee. 1971. Fuel of respiration of the outer medulla. Am. J. Physiol. 220:1693-1700.

39. Biava, C., A. Grossman, and M. West. 1966. Ultrastructural observations on renal glycogen in normal and pathologic human kidneys. Lab. Invest. 15:330356.

40. Holck, P., and R. Rasch. 1993. Structure and segmental localization of glycogen in the diabetic rat kidney. Diabetes. 42:891-900.

41. Wirthensohn, G., and W. Guder. 1986. Renal substrate metabolism. Physiol. Rev. 66(2):469-497.

42. DeFronzo, R. A., C. R. Cooke, R. Andres, G. R. Faloona, and P. J. Davis. 1975. The effect of insulin on renal handling of sodium, potassium, calcium and phosphate in man. J. Clin. Invest. 55:845-855.

43. DeFronzo, R. A., M. Goldberg, and Z. Agus. 1976. The effects of glucose and insulin on renal electrolyte transport. J. Clin. Invest. 58:83-90.

44. Cryer, P. E. 1992. Glucose homeostasis and hypoglycemia. In Williams Textbook of Endocrinology. J. D. Wilson and D. W. Foster, editors. McGrawHill, Inc., New York. 1223-1254.

45. Service, F. J. 1992. Hypoglycemias. In Cecil Textbook of Medicine. J. B Wyngaarden and L. H. Smith, Jr., editors. W.B. Saunders Company, Philadelphia, PA. 41-53.

46. Magnusson, I., D. L. Rothman, L. D. Katz, R. G. Shulman, and G. I. Shulman. 1992. Increased rate of gluconeogenesis in type II diabetes mellitus; A 13C nuclear magnetic resonance study. J. Clin. Invest. 90:1323-1327.

47. DeFronzo, R. A. 1988. The triumvirate: beta-cell, muscle and liver; a collusion responsible for NIDDM. Diabetes. 37:667-687.

48. Fischer, K. F., J. A. Lees, and J. H. Newman. 1986. Hypoglycemia in hospitalized patients. $N$. Engl. J. Med. 315:1245-1250.

49. Cotran, R. S., V. Kumar, and S. L. Robbins. 1989. The kidney. In Robbins Pathologic Basis of Disease. W.B. Saunders Company, Philadelphia, PA 1011-1081 